\title{
Pemanfaatan Kain Flanel sebagai Aneka Kerajinan Tangan untuk Menumbuhkan Jiwa Kewirausahaan bagi Remaja Putus Sekolah di Desa Permata, Boalemo
}

\author{
Lanto Miriatin Amali ${ }^{1}$, Melizubaida Mahmud ${ }^{2}$ \\ 1, 2 Universitas Negerı Gorontalo
}

\begin{tabular}{ll}
\hline Article History & ABSTRACT \\
\hline Received 22.11.2018 & UTILIZATION OF FLANNEL AS HANDICRAFTS TO GROW \\
Received in revised form & ENTREPRENEURSHIP FOR SCHOOL DROPOUTS IN PERMATA \\
Accepted 01.04.2019 & VILLAGE, BOALEMO. The devotion program aims to empower teenagers \\
Available online 30.04.2019 & who drop out of school in the gem village of Paguyaman district in Boalemo \\
& district through the use of flannel fabrics while fostering an entrepreneurial \\
& spirit. The proposal and method of solving problems in this Community \\
& Service program is to train teenagers who drop out of school to make various \\
& kinds of handicrafts from flannel, develop this flannel fabric motif in \\
& accordance with the characteristics of Permata Village, and develop \\
& marketing distribution especially in Boalemo district. The partner in this \\
& service Ranti Taylor with the owner's name is Abas Aminah whose business \\
& is convection and the only one is in Permata Village. This can make it easier \\
& for teenagers to drop out of school to conduct training while developing \\
& handicrafts from flannel fabrics from various motives while creating new \\
& designs so that they are more skilled in making them. \\
& Keywords: Entrepreneurship, Flannel, Handicraft.
\end{tabular}

This is an open access article distributed under the terms of the Creative Commons Attribution 4.0 International License, which permits unrestricted use, distribution, and reproduction in any medium, provided the original work is properly cited. (c) 2019 Lanto Miriatin Amali, Melizubaida Mahmud.

\section{PENDAHULUAN}

Desa Permata merupakan salah satu desa yang berada di Kecamatan Paguyaman Kabupaten Boalemo provinsi gorontalo yang letak geografisnya $0^{\circ} 23^{\prime} 55^{\prime}-0^{\circ} 55^{\prime} 38^{\prime \prime}$ lintang utara dan $120^{\circ} 01^{\prime} 12^{\prime \prime}-122^{\circ} 39^{\prime} 17^{\prime \prime}$. Kabupaten Boalemo berada di posisi sebelah barat dari provinsi gorontalo, dan dilalui oleh jalur utama jalan trans Sulawesi. Selain itu Kabupaten Boelemo mempunyai kawasan perairan (laut teluk tomini) di wilayah bagian selatan, dengan garis pantai $72 \mathrm{~km}$ mulai dari Desa Girisa Kecamatan Paguyaman sampai dengan Desa Mananggu Kecamatan Mananggu. Jumlah dan kepadatan penduduk Kabupaten Boalemo itu sendiri khusus Kecamatan Paguyaman sampai dengan tahun 2014 sebanyak 
24,328 jiwa dimana sudah termasuk penduduk yang ada di desa permata yang rata-rata tingkat pendidikannya berdasarkan data dari tahun 2012 sampai dengan 2014 untuk lulusan SD/MI angka partisipasi kasarnya (APK) sebesar 96,79 \%; lulusan SMP/Mts sebesar 84,01; lulusan SLTA sebesar 64,47\%.

Berdasarkan data di atas, maka yang menjadi permasalahannya adalah dimana remaja yang lulusan SLTA begitu kecil untuk bisa menempuh pendidikan sampai dengan SLTA, hal ini memungkin karena banyak remaja yang putus sekolah diakibatkan oleh pendapatan dari orang tua mereka kurang atau tidak ada sama sekali untuk membiayai pendidikan anak-anak mereka sampai dengan selesai. Untuk itu anak-anak remaja yang telah putus sekolah sebaiknya diberikan pelayanan pendidikan non formal khususnya keterampilan yang bisa menumbuhkan jiwa kewirausahaan melalui pemanfaatan kain flannel ini, dimana kain flannel ini selain sangat mudah didapat harganya pun terjangkau sehingga modal untuk membuat berbagai macam kerajinan tangan dari kain flannel ini sedikit tetapi keuntungan yang didapatkan cukup lumayan untuk memulai suatu usaha baru. Kain flannel itu sendiri merupakan salah satu jenis kain yang paling banyak dimanfaatkan untuk membuat aneka jenis kerajinan tangan. Salah satu alasan kenapa kain flannel dipilih sebagai bahan kerajinan tangan adalah tekstur dari kain ini yang mudah dibentuk dan harganya yang murah, selain itu untuk mendapatkan kain ini juga cukup mudah, dari 1 meter kain flanen yang harganya Rp. 20.000 bisa untuk membuat aneka kerajinan tangan seperti bros bunga aneka warna, telur hias berbagai motif, aneka boneka dengan dengan karakter lucu, tiruan makanan dari kain flannel, tempat tissue dengan berbagai macam model, gantungan kunci dengan karakter boneka lucu, tempat pensil dengan berbagai model.

Melalui program pengabdian pada masyarakat ini diharapkan bahwa anak-anak remaja yang telah putus sekolah mendapatkan pendidikan non formal berupa keterampilan dengan memfaatkan kain flannel ini sebagai kerajinan tangan sekaligus menumbuhkan jiwa kewirausahaan pada anak-anak remaja yang ada di desa Permata Kecamatan Paguyaman Kabupaten Boalemo sekaligus hasil dari kerajinan tangan ini bisa diterima oleh masyarakat luas khususnya Provinsi Gorontalo sebagai salah satu produk baru yang dikembangkan oleh remaja-remaja Desa Permata yang telah putus sekolah dengan mengembangkan berbagai macam model lagi yang dibuat dari pemanfaatan kain flannel ini.

Untuk menyelesaikan masalah di atas, maka perlu adanya pendampingan yang efisien untuk menumbuhkan jiwa kewirausahaan bagi remaja-remaja yang telah putus sekolah ini dengan beberapa tahapan kegiatan sebagai berikut:

1) Melatih remaja-remaja yang telah putus sekolah yang ada di Desa Permata untuk membuat berbagai macam kerajinan tangan dari kain flannel ini.

2) Mengembangkan motif kain flannel ini sesuai dengan ciri khas dari Desa Permata Kecamatan Paguyaman Kabupaten Boalemo

3) Mengembangkan distribusi pemasaran terutama di Kabupaten Boalemo.

\section{METODE PELAKSANAAN}

Program Pengabdian masyarakat ini dilaksanakan dengan metode ceramah dan tanya jawab sekaligus dengan metode penyuluhan, dimana kegiatan tersebut dipraktekkan secara langsung oleh remaja-remaja putus sekolah serta ibu-ibu rumah 
tangga yang ada di Desa Permata Kecamatan Paguyaman Kabupaten Boalemo yang ingin ikut berpartisipasi dalam program ini. Dalam program ini, kami memberikan pengetahuan tentang manajemen bisnis dalam memulai suatu usaha baru sekaligus memberikan keterampilan dalam membuat berbagai macam produk-produk yang berasal dari kain flanel ini yang bisa dijadikan daya jual dalam rangka menumbuhkan jiwa kewirausahaan bagi perempuan-perempuan yang telah putus sekolah sekaligus meningkatkan pendapatan bagi keluarga mereka.

\section{HASIL DAN PEMBAHASAN}

Jiwa kewirausahaan bagi remaja putus sekolah sangat tidak mudah untuk dimotivasi, karena berbagai alasan yang dikemukakan oleh mereka adalah kurangnya modal, serta kurangnya keahlian (softskill) dalam memulai suatu usaha baru sehingga kebanyakan dari mereka sudah banyak yang menikah muda. Untuk itu dengan adanya program pelatihan ini, kami berusaha memberikan motivasi serta memfasilitasi seorang mentor atau orang yang ahli dalam membuat suatu kerajinan tangan yang sangat mudah dibuat tetapi bisa menghasilkan pendapatan dengan modal yang kecil.

Kain flanel itu sendiri merupakan jenis kain yang dibuat dari serat wol tanpa tenun, dibuat dengan proses pemanasan dan penguapan sehingga menghasilkan kain dengan beragam tekstur dan jenis (tergantung bahan pembuatannya). Kain flanel mudah dijumpai di pasaran, dengan harga yang relatif terjangkau. Kain ini memiliki ketebalan dan tektur yang beragam. Kelebihan dari kain ini adalah mudah dibentuk dan pada proses penjahitan tidak perlu dilipat seperti kain yang lain. Bahan kain flanel itu sendiri harga sangat terjangkau, sehingga dalam pembuatan kerajinan tangan itu sendiri tidak banyak memerlukan keahlian tertentu tetapi dalam hal ini yang di perlukan disini adalah ide-ide atau gagasan serta kreativitas tertentu agar karya yang kita hasilkan memuaskan dan menarik untuk dilihat sehingga hal ini juga menarik orang untuk membelinya. Contohnya seperti Kotak tissue yang dibuat dengan berbagai macam warna serta aksesoris yang melekat di atasnya, gantungan Kunci dengan berbagai model bisa bentuk huruf, bentuk buah dll, kemudian bisa juga dibuat bros sebagai aksesoris jilbab atau baju dengan berbagai macam model atau mencampurkan berbagai macam warna yang bisa menarik minat pembeli.

Demi kelancaran pelaksanaan kegiatan pengabdian ini kami di bantu oleh beberapa mahasiswa yang dipilih untuk melaksanakan kegiatan ini, dan hasil dari kegiatan tersebut kami mendapatkan respon yang baik dari remaja-remaja putus sekolah ini, dimana mereka mau diajak dan dilatih keterampilan mereka dalam membuat berbagai macam kerajinan tangan dari kain flannel ini. Selain itu, ada beberapa masyarakat setempat selain para remaja-remaja putus sekolah ini seperti para ibu-ibu rumah tangga ikut pula dalam pelaksanaan kegiatan pelatihan ini serta bahkan sudah mulai ada yang memulai membentuk kelompok kecil usaha untuk dapat memulai usaha mereka dalam pembuatan kerajinan tangan seperti bros atau gantungan kunci yang bisa dijadikan sebagai usaha mereka dalam souvenir-souvenir pernikahan maupun ulang tahun di desa mereka. Untuk itu pemanfaatan kain flanel ini sebagai kerajinan tangan untuk menumbuhkan jiwa kewirausahaan bagi remaja putus sekolah ini merupakan salah satu peluang usaha yang mudah dengan membutuhkan modal yang kecil tetapi bisa menghasilkan nilai tambah bagi perekonomian remaja putus sekolah yang berada di Desa Permata Kecamatan Paguyaman Kabupaten Boalemo. 


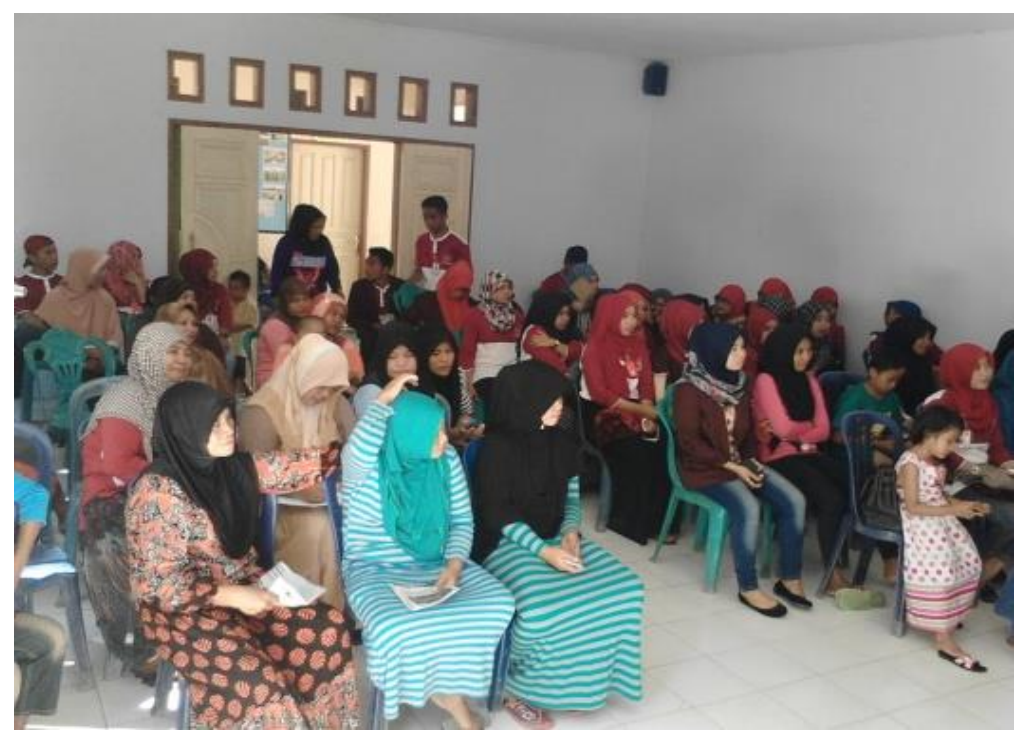

Gambar 1. Pembukaan Kegiatan Pelatihan Pemanfaatan Kain Flanel

Dalam rangka menumbuhkan jiwa kewirausahaan bagi remaja putus sekolah di Desa Permata ini sekaligus bisa menopang dan memberikan pendapatan bagi mereka, tentunya hal tersebut dapat diwujudkan dengan memberikan pelatihan tentang Pemanfaatan kain flanel ini sebagai kerajinan tangan sekaligus membantu perekonomian bagi keluarga mereka. Hal ini bisa terlaksana apabila remaja putus sekolah ini mau berusaha serta mau berlatih dalam membuat suatu usaha baru, oleh karena itu sangatlah diperlukan motivasi, ide-ide, serta gagasan dalam menciptakan karya melalui kerajinan tangan ini.

Motivasi, ide-ide, serta gagasan merupakan salah satu faktor yang paling kuat untuk menumbuhkan jiwa kewirausahaan ini, dan harus dimulai dari diri sendiri untuk bisa meningkatkan pendapatan bagi keluarga. Hal ini harus difasilitasi oleh pemerintah dan seluruh steakholder maupun pihak ketiga termasuk perguruan tinggi yang menjadi motor penggerak bagi remaja putus sekolah yang merupakan bagian dari tri dharma perguruan tinggi. Berikut salah satu contoh kerajinan dari pemanfaatan kain flannel ini, dimana bahan dan peralatannya terdiri dari Kain Flanel, Benang, Lem Lilin, Putik, Payet, Kapas Dacron, Alat Tembak, Jarum, Gunting, Tempat Sendok, Tempat Tissue, Tempat Toples, Kertas Stabilo warna, Isolasi, Lem UHU, Isolasi Gliter Rol Besar, Benang Elatis. Selanjutnya untuk salah satu tahapan pembuatan hiasan tempat tissue sebagai berikut: (1) ukur panjang dan tinggi kotak tissue,(2) pinggiran-pinggiran yang terbuka dari kain flanel yang telah dipotong tersebut disatukan dengan cara menjahit dengan teknik tusuk feston, (3) Setelah semua telah bersatu lepas kotak tissue bagian atas, lalu beri lingkaran dengan menggunakan pensil untuk tempat keluarnya tissue, (4) Gunting lingkaran yang dibuat tadi, (4) Tempelkan flanel warna lain yang berbentuk garis-garis dengan lem lilin, (5) Selanjutnya tempelkan aplikasi lain yang berbentuk buah, bunga yang terbuat dari kain flenel juga agar terlihat cantik. 


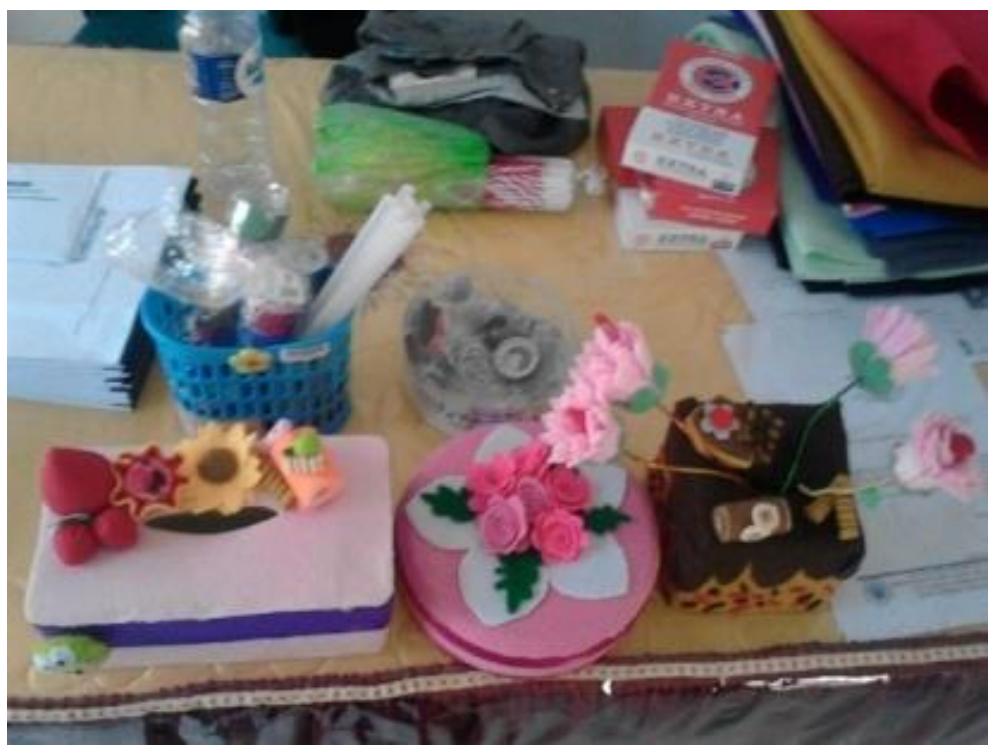

Gambar 2. Aneka Produk Kerajinan yang dihasilkan

Selain pembuatan kerajinan tangan di atas ide-ide atau gagasan lainnya yang bisa dibuat melalui kerajinan tangan oleh remaja putus sekolah ini adalah tempat ponsel dengan hiasan lucu sekaligus menambah keindahan casing ponsel, jenis-jenis makanan atau kue seperti donat, kue, udang, bantal-bantal hiasan dengan berbagai model, karakter dari kelapa boneka, selanjutnya ada sepatu bayi yang terbuat dari kain flanel, boneka jari untuk mainan anak-anak. Serta model-model bunga yang cantik yang bisa dijadikan nilai tambah untuk meningkatkan perekonomian keluarga. Untuk kreatifitas, ide serta gagasan sangatlah dibutuhkan dalam menghasilkan hasil karya yang unik yang terbuat bahan kain flanel ini.

\section{SIMPULAN}

Pada akhir pelatihan ini diharapkan jiwa-jiwa kewirausahaan bagi remaja-remaja putus sekolah bisa berkembang tanpa mempelajarinya secara formal melainkan secara otodidak serta memiliki soft skill Sekaligus diharapkan memiliki motivasi yang sangat besar untuk bisa memulai suatu usaha yang baru dengan cara yang mudah, murah serta meningkatkan pendapatan bagi keluarga di desa Permata Kecamatan Paguyaman Kabupaten Boalemo.

\section{REFERENSI}

Alma, B. (2010). Kewirausahaan. Jakarta: Alfabeta.

Kampoong Informasi (2015). Jenis kain flanel dan harganya. Retrieved July 13, 2018 from https://www.kampoong.com/kerajinan/jenis-kain-flanel-dan-harganya.html

Karmidin, A. (2009). Menumbuhkan Jiwa Wirausaha. Yogyakarta: Pustaka Pelajar.

Kasali, R. (2010). Wirausaha mandiri muda. Jakarta: Gramedia Pustaka Utama. 
Kothler, P. (1997), Manajemen pemasaran. (Diterjemahkan oleh Hendra Teguh dari buku Marketing Management $9^{\text {th }}$. Jakarta: Prenhallindo.

Rizky, F. (2016). 19 ide kerajinan tangan dari kain flanel ini layak kamu coba di rumah. Retrieved July 13, 2018 from https://www.fatinia.com/kerajinan-tangan-dari-kain-flanel/

Setiawan, A. (2011). Jejak Langkah wirausaha (Motivasi, histori, teknis usaha). Jakarta: Alfabeta.

Suherman, E. (2011). Busssiness Entrepreneur. Jakarta: Alfabeta.

Yahya, H. (2010). Wirausaha bermodal nol rupiah. Jakarta: Elex Komputindo. Jakarta. 